\title{
Isolation of osteogenic progenitors from human amniotic fluid using a single step culture protocol
} Ivana Antonucci ${ }^{1,2}$, Irene Iezzi ${ }^{3}$, Elisena Morizio ${ }^{3}$, Filiberto Mastrangelo ${ }^{4}$, Andrea Pantalone ${ }^{5}$, Monica Mattioli-Belmonte ${ }^{6}$, Antonio Gigante ${ }^{6}$, Vincenzo Salini ${ }^{5}$, Giuseppe Calabrese ${ }^{1,3}$, Stefano Tetè ${ }^{4}$, Giandomenico Palka ${ }^{1,3}$ and Liborio Stuppia*1,2,7

Address: ${ }^{1}$ Department of Biomedical Sciences, "G. d'Annunzio" University, Chieti-Pescara, Italy, ${ }^{2}$ Aging Research Center (CE.S.I.), "G. d'Annunzio" University Foundation, Chieti-Pescara, Italy, ${ }^{3}$ Human Genetics Division, Pescara Hospital, Pescara, Italy, ${ }^{4}$ Department of Oral Sciences "G. d'Annunzio" University, Chieti-Pescara, Italy, ${ }^{5}$ Orthopedic and Traumatologic Division, "G. d'Annunzio" University, Chieti-Pescara, Italy, ${ }^{6}$ Department of Molecular Pathology and Innovative Therapies, Polytechnic University of Marche, Ancona, Italy and ${ }^{7}$ Institute for Molecular Genetics, National Research Council (CNR), Bologna, Italy

Email: Ivana Antonucci - antonucciivana@libero.it; Irene Iezzi - ireneiezzi@tiscali.it; Elisena Morizio - e.morizio@virgilio.it; Filiberto Mastrangelo - filibertomastrangelo@hotmail.com; Andrea Pantalone - pantaloneandrea@libero.it; Monica MattioliBelmonte - m.mattioli@univpm.it; Antonio Gigante - agigante@iol.it; Vincenzo Salini - v.salini@unich.it; Giuseppe Calabrese - gcalabr@unich.it; Stefano Tetè - tete@unich.it; Giandomenico Palka - gdpalka@unich.it;

Liborio Stuppia* - stuppia@unich.it

* Corresponding author

Published: 16 February 2009

BMC Biotechnology 2009, 9:9 doi:10.1 186/1472-6750-9-9
Received: 23 April 2008

Accepted: 16 February 2009

This article is available from: http://www.biomedcentral.com//472-6750/9/9

(c) 2009 Antonucci et al; licensee BioMed Central Ltd.

This is an Open Access article distributed under the terms of the Creative Commons Attribution License (http://creativecommons.org/licenses/by/2.0), which permits unrestricted use, distribution, and reproduction in any medium, provided the original work is properly cited.

\begin{abstract}
Background: Stem cells isolated from amniotic fluid are known to be able to differentiate into different cells types, being thus considered as a potential tool for cellular therapy of different human diseases. In the present study, we report a novel single step protocol for the osteoblastic differentiation of human amniotic fluid cells.

Results: The described protocol is able to provide osteoblastic cells producing nodules of calcium mineralization within 18 days from withdrawal of amniotic fluid samples. These cells display a complete expression of osteogenic markers (COLI, ONC, OPN, OCN, OPG, BSP, Runx2) within 30 days from withdrawal. In order to test the ability of these cells to proliferate on surfaces commonly used in oral osteointegrated implantology, we carried out cultures onto different test disks, namely smooth copper, machined titanium and Sandblasted and Acid Etching titanium (SLA titanium). Electron microscopy analysis evidenced the best cell growth on this latter surface.

Conclusion: The described protocol provides an efficient and time-saving tool for the production of osteogenic cells from amniotic fluid that in the future could be used in oral osteointegrated implantology.
\end{abstract}




\section{Background}

Amniotic Fluid Cells (AFCs) can be classified in epitheloid E-type cells, amniotic fluid specific AF-type cells and fibroblastic F-type cells (1). In recent years, different reports have demonstrated that presence in human amniotic fluid of stem cells (AFS) able to differentiate into multiple lineages [1-8]. Very recently, the ability of clonal AFS to produce cell types inclusive of all embryonic germ layers was demonstrated $[9,10]$. Unlike embryonic stem cells, AFS have been showed to be not tumorigenic after transplantation in mice [9]. As a consequence, several studies have suggested the usefulness of these cells for therapeutic purposes [11-16]. Osteoblastic cells derived from AFS could be useful for bone regeneration after traumatic or degenerative damage $[17,18]$. In fact, osteoblastic progenitors obtained from amniotic fluid could be used to engineer the craniofacial structures whose natural development is regulated by mesenchymal cells originating from the neural crest, avoiding long and difficult therapies of bone augmentation with intra-oral or extra oral donor site $[19,20]$. In order to obtain the best results in craniofacial tissue engineering, great relevance is assumed by the use of scaffolds able to accommodate cell growth and tissue genesis. To date, implants with different surface treatments are investigated to define the best surface morphology for a good osteoblastic cell proliferation and osseointegration around implant [21-25].

The aim of the present study is to evaluate the ability of human AFS to differentiate into osteogenic cells using a novel single step culture protocol, and to test their growth ability on different implant surfaces.

\section{Results}

Osteoblastic differentiation was obtained in the present study using two different culture protocols of amniotic fluid cells. In the first protocol (Protocol 1), Amniotic Fluid Mesenchymal Stem cells (AFMSCs) were transferred in osteogenic medium at passage 6 , while in the second protocol (Protocol 2), pellets of amniotic fluid samples were directly resuspended in osteogenic medium without the selection of AFMSCs.

A flow chart describing the different timing of the two protocols used in this study is reported in Figure 1.

In Protocol 1, seven days after the initiation of the primary culture, fibroblast-like cells appeared both isolated and as colonies in the culture flask (Figure 2a). After 20-22 days of culture, at $70-80 \%$ confluence (Figure $2 \mathrm{~b}$ ), cells were treated with trypsin and EDTA and collected. RT-PCR analysis, carried out on RNA extracted from the cells at this stage, evidenced the presence of genes previously reported as expressed in AFMSCs [26], namely SDF1, CXCR4, Oct-4, SCF, GATA-4, Vim, FGF-5, Pax-6, NCAM,

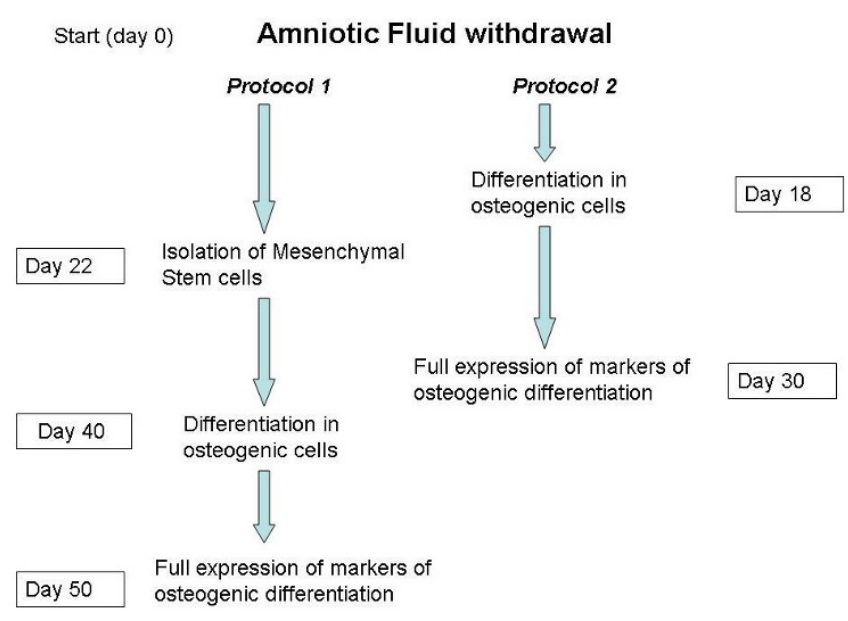

Figure I

Flow chart showing the different steps of the two protocols for the production of osteogenic cells from amniotic fluid.

AFP, BMP-2 (Figure 3). Cells collected at day 20-22 were transferred and cultured in the osteogenic medium. After 18 days of culture in osteogenic medium (day 40 from withdrawal), the cells showed $70-75 \%$ confluence, and the presence of aggregates or nodules of calcium mineralization was appreciable. The number and size of these aggregates increased in the following days. Cells directly cultured in osteogenic medium (Protocol 2) reached 70$75 \%$ confluence after 18 days from withdrawal, and became over confluent in the following days (Figure 2c). In the following days the appearance of the first aggregates of calcium mineralization was observed (Figure 2). Alizarin Red staining confirmed the presence of biomineralization (Fig. 2e). An increase in the number and size of aggregates during the time was observed also in these cultures (Figure 2f). Cell count carried out on 5 cultures performed with protocol 2 at day 30 from withdrawal demonstrated the presence of cell number ranging from $8,9 \times 10^{6} 9,7 \times 10^{6}$ cells.

RT-PCR analysis carried out at day 50 (protocol 1) or 30 (Protocol 2) from withdrawal, showed expression of COL1, ONC, OPN, OCN, OPG, BSP and Runx2, typical markers of the osteogenic differentiation (Figure 4). The same genes were not expressed in fresh amniotic fluid samples, analyzed as negative control (not showed).

In order to evaluate the growth ability of osteoblastic cells obtained by Protocol 2 on different surfaces commonly used in oral implantology, cultures were carried out on smooth copper, machined titanium and Sandblasted and Acid Etching titanium (SLA titanium) test disks, and evaluated using Electron Scanning Microscopy. Titanium is 

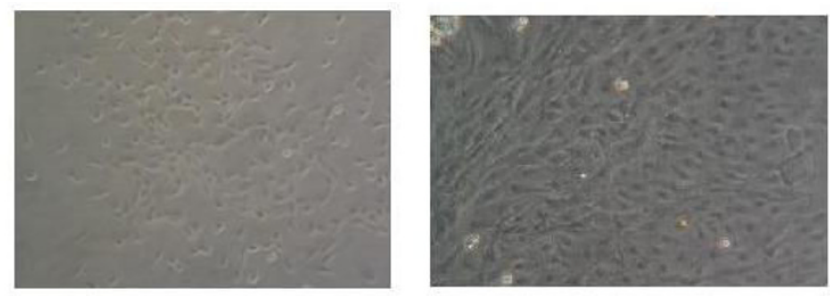

a)

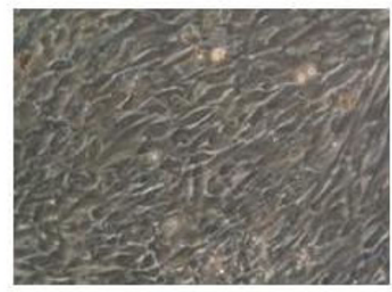

c)

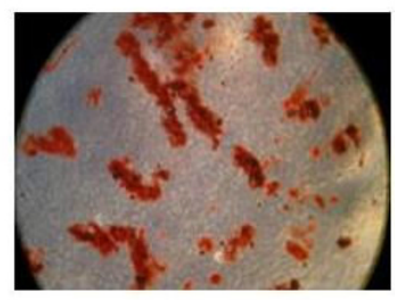

e) b)

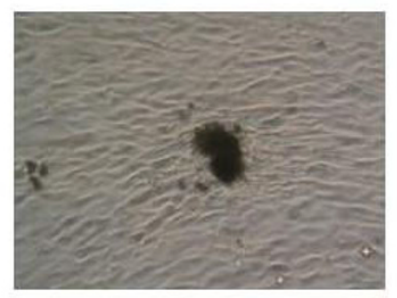

d)

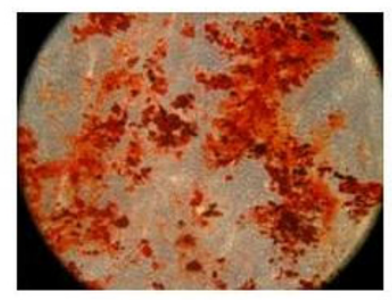

f)

Figure 2

a) Fibroblast-like cells (AFMSCs) obtained after 7 days of amniotic fluid culture (Protocol I); b) Confluence of AFMSCs after 22 days of amniotic fluid culture (Protocol I); c) over confluent osteoblastic cells after 20 days of amniotic fluid culture in osteogenic medium (Protocol 2); d) nodules of calcium mineralization, osteoblastic cells (Protocol 2); e) Alizarin Red Staining of osteoblastic cells obtained after 22 days of amniotic fluid culture. Red spots indicate the presence of calcium mineralization; f) Alizarin Red Staining of osteoblastic cells after 30 days of amniotic fluid culture. Note the increase in the number and size of aggregates of calcium mineralization.

universally considered as the first-rate material for oral osseointegrated implantology. Additional treatments on commercially pure (c.p.) titanium surface provide further enhancement of bone-to-implant contact, thus reducing the osseointegration period, improving treatment outcome and increasing applicability to poor bone quality. The investigation of implants with different surface treatments, both in vitro and in vivo, is a crucial point in order to define the surface morphology which could permit a good osteoblastic cell proliferation and osseointegration around implant. In our experiments, adherent cells were not detected on smooth copper surface (negative control)
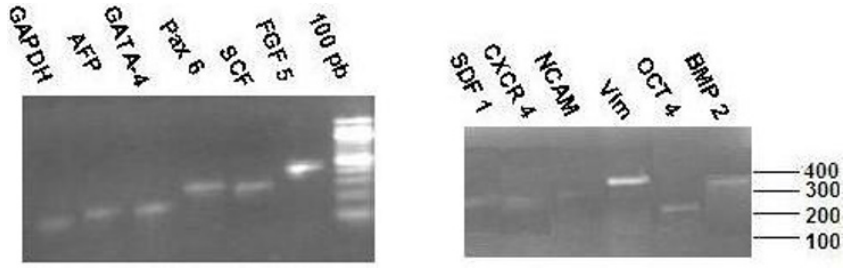

Figure 3

RT-PCR analysis of AFMSCs at day 20 of culture (protocol I).

at day 3, while different behaviour of osteoblastic-like cells were observed on machined titanium and SLA titanium surfaces. On machined titanium surfaces, few adherent cells were observed around the titanium disk. On the contrary, adherent cells were found to cover the whole surface of SLA titanium disk (Figure 5a). Cell aggregates were arranged almost uniformly and formed a single layer cell culture on the disk surface (Figure 5b). At high magnification philophodia surrounding cell surfaces were clearly visible (Figure $5 \mathrm{c}-\mathrm{d}$ ).

In order to evaluate the mitotic stability of cells, cytogenetic investigation was carried out on Protocol 2 cultures at day 30, showing normal diploid karyotype in all the investigated metaphases.

\section{Discussion}

Different protocols have been reported in literature for the differentiation of osteogenic cells starting from amniotic fluid. Some authors reported the use of immunoselection with c-Kit specific antibodies in order to isolate AFS starting from confluent human amniocentesis cultures, followed by proliferation of AFMSCs under appropriate culture conditions, and finally osteoblastic differentiation after several days of culture $[8,9]$. On the other hand, other groups cultured unselected amniotic fluid cells in
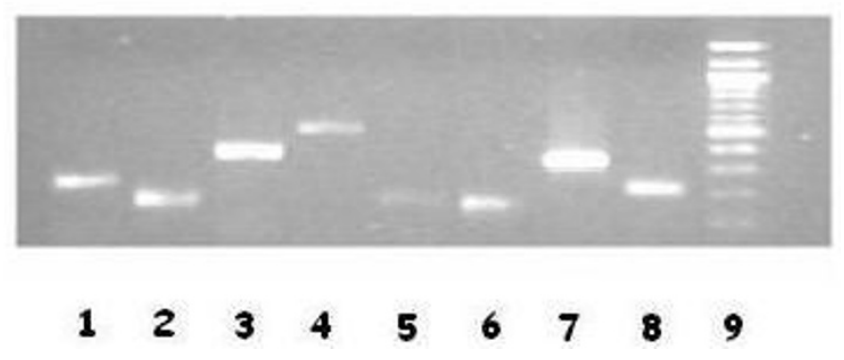

\section{Figure 4}

RT-PCR analysis of osteoblastic cells at $\mathbf{3 0}$ days of culture (protocol 2). Line I = ONC; Line 2 = Runx2; Line 3 = OCN; Line 4 = BSP; Line 5 = OPN; Line 6 = COL I; Line 7 = OPG; Line 8 = GAPDH; Line $9=100$ bp molecular weight marker. 


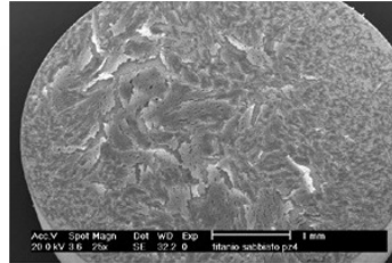

a)

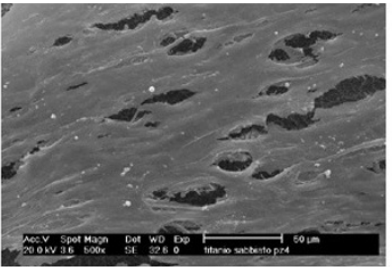

b)

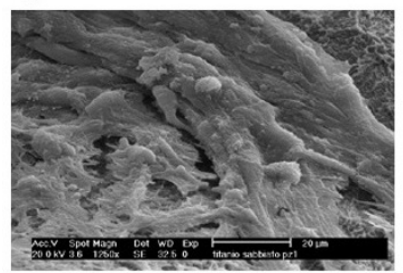

c)

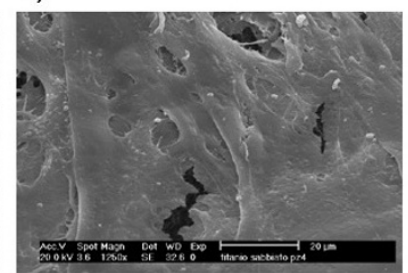

d)

Figure 5

Scanning Electron Microscope analysis of osteoblastic cells cultured on SLA titanium disks. a) $22 \times$, b) 500x: adherent cells covering the whole surface of SLA titanium disk; c) I250×, d) 1250x: evidence of philophodia surrounding cell surfaces.

media allowing the proliferation of AFMSCs, and subsequently induced their differentiation in osteoblastic cells $[1,4,5]$.

In the present study, we demonstrated the ability of human AFS to differentiate into osteogenic cells using a single step culture procedure, allowing a 20 days reduction of the culture time as compared to previously reported protocols. This could represent an important point in the view of a possible therapeutic application of these cells. Amniotic fluid samples, directly resuspended in osteogenic medium without the selection of AFMSCs, were able to produce osteogenic cells after 18 days from the withdrawal as demonstrated by Alizarin Red staining. RT-PCR analysis showed the full expression of all osteogenic markers typical of late stage osteoblasts after 30 days of colture, while the same expression pattern is showed after 50 days from withdrawal by cells obtained using conventional protocols. Cytogenetic investigation, carried out at day 30 on cells obtained by the single step protocol, showed normal diploid karyotype in all the investigated samples, thus confirming the mitotic stability of cells obtained using this procedure. Cell count performed on cultures carried out with protocol 2 showed the presence at day 30 from withdrawal of about 9,7 × $10^{6}$ cells starting from as little as $2-3 \mathrm{ml}$ of amniotic fluid. Although the direct culture of AFS cells in osteogenic medium likely induces a complete cell differentiation within 30 days, with arrest of cell proliferation, the amount of cells obtained with this protocol fits well with the cell number required for preclinical studies in animal models and for local transplant in human. Since this latter approach would likely represent the gold standard for a future clinical application in odontoiatric and orthopaedic implantology, the cell number obtained using our direct protocol appears to be sufficient for future local therapeutic purposes.

In order to test the ability of osteoblastic cells obtained from amniotic fluid to proliferate onto surfaces commonly used for craniofacial implantology, and to evaluate their usefulness for tissue engineering, we tested these cells on disks with machined titanium and SLA titanium surfaces. Electron microscopy observation showed a good growth and adherence of osteoblastic cells on this latter surface. This result indicates the excellent biocompatibility of osteoblastic cells obtained from amniotic fluid with SLA titanium scaffolds currently utilized in dental implant.

\section{Conclusion}

The protocol described in the present study shows the ability of producing osteoblastic cells from amniotic fluid samples in a very short time, being these cells fully differentiated within one month from withdrawal. Although osteoblastic progenitors can be successfully obtained from bone marrow stromal cells, the use of amniotic fluid as a source of these cells is of relevance since AFS can be easily obtained from routine clinical amniocentesis specimens that would otherwise be discarded. Thus, it is possible to suggest that banking of these stem cells will provide in the future a relevant source both for autologous therapy in the adulthood and for the transplant in HLA matched recipients.

\section{Methods \\ Isolation and culture of mesenchymal stem cells from amniotic fluid (AFMSCs)}

Amniotic fluid samples were obtained from 11 women undergoing amniocentesis for prenatal diagnosis at 1619 weeks of pregnancy after written informed consent. The study has been approved by the Ethics Committee for Biomedical Research of the "G. d'Annunzio" University, Chieti. For each sample, 2-3 ml of amniotic fluid, corresponding to a cell number ranging from $2 \times 10^{3}$ to $2 \times 10^{6}$ [1] were centrifuged for 10 minutes at $1800 \mathrm{rpm}$. Pellets were resuspended in Iscove's modified Dulbecco's medium supplemented with 20\% FBS, $100 \mathrm{U} / \mathrm{ml}$ penicillin, $100 \mu \mathrm{g} / \mathrm{ml}$ streptomycin (Sigma), $2 \mathrm{mM}$ L-glutamine, $5 \mathrm{ng} / \mathrm{ml}$ basic fibroblast growth factor (FGF2) and incubated at $37^{\circ} \mathrm{C}$ with $5 \%$ humidified CO2. After 7 days, non-adherent cells were removed and the adherent cells allowed to growth in the same medium, which was changed each 4 days. When culture reached confluence (about 20 days after the primary culture), cells were treated with $0,05 \%$ trypsin and $0,02 \%$ EDTA, then counted and replaced in $25 \mathrm{~cm}^{2}$ culture flasks. 


\section{Osteogenic differentiation}

Two different culture protocols were used for osteogenic differentiation of amniotic fluid cells. In the first protocol (Protocol 1), AFMSCs cells at passage 6 were transferred in osteogenic medium consisting of the above described medium with the addition of $150 \mu \mathrm{g} / \mathrm{ml} \beta$ Glycerophosphate, $50 \mu \mathrm{g} / \mathrm{ml}$ ascorbic acid, and $10^{-8} \mathrm{M}$ dexamethasone. In the second protocol (Protocol 2), pellets of amniotic fluid samples were directly resuspended in osteogenic medium in $75 \mathrm{~cm}^{2}$ flasks without the selection of AFMSCs. At day 8 from withdrawal, colony forming cells were counted, showing a number ranging from 20 to 20.000 in the different cultures. To visualize calcium sediments, cells treated with Protocol 2 were stained at different times $(19,22$ and 30 days from withdrawal) with Alizarin Red S solution, according to Gregory et al. [27]. Mineralization was demonstrated by the presence of red depositions. All reagents used for cells culture and staining were purchased by Sigma-Aldrich (Milano, Italy)

\section{Culture on different surfaces}

Three test disks (diameter $10 \mathrm{~mm}$, thickness $5 \mathrm{~mm}$ ) for each different surface, namely smooth copper, machined titanium and Sandblasted and Acid Etching titanium (SLA titanium), were used in this study Geometric surface morphology of Machined Titanium test disks was obtained with turning machined treatment with formation of titanium micro-parallel walls. Sandblasted and Acid Etching titanium (SLA titanium) test disks were obtained by $\mathrm{TiO} 2$ particles being applied to the surface and two phases of etching with fluoridric acid followed by a second acid attack by sulphuric-hydrochloric acid with irregular distributed porosity structure of micro-deep valleys alternated to elevated sharp crests. To preliminary characterize the surface morphology, test disks have been evaluated by means of Scanning Electron Microscopy (SEM) imaging (LEO $435 \mathrm{VP}$, Cambridge, UK) at about 15-20 kV, high vacuum mode. The surface roughness of the specimens were measured with a stylus profilometer (ANSI/ASME B46.1 1-2002) and a gloss meter $\left(45^{\circ}-90^{\circ}\right.$ sensor angle, 1-10 range, DIN 16537). Differences between treatment groups were evaluated using an analysis of variance at the 95\% confidence level and parametric Newman-Keuls multiple comparison test at $\mathrm{p}=0.05$ significance level. After differentiation, at day 15, osteoblastic cells obtained using protocol 2 were divided in three groups and 3,7 $\times$ $10^{4}$ cells were seeded onto each of the three different test disks. When 70\% confluence was observed (after 2-3 days of culture), cells were prepared and analysed by SEM. The entire culture protocol on test disks was repeated two times.

\section{Scanning Electron microscopy}

For SEM analysis, specimens cells were fixed in 2\% gluteraldehyde in $0.1 \mathrm{M}$ cacodylate buffer ( $\mathrm{pH} 7.4$ ). To preserve the lipid structures, specimens were gently washed in 0.2
M cacodylate buffer ( $\mathrm{pH} 7.4$ ) with the addition of $0.15 \mathrm{M}$ saccharose for three changes every 20 minutes, post-fixed in $1 \%$ osmium tetroxide at room temperature for 1 hours, then given two quick changes of the previous buffer and gradually dehydrated in increasing ethanol concentrations (from 25 to $100 \%, 15 \%$ steps). Samples were then carried through critical point drying (CPD) according to standard procedure using liquid carbon dioxide, mounted on aluminium stubs, gold-sputtered and observed with a Philips XL20 Scanning Electron Microscope (SEM Philips XL 20; FEI, Eindhoven, The Netherlands) at $20 \mathrm{KV}$, high vacuum mode. Images were stored in TIF format with $1024 \times 768$ Grid of Pixels

\section{RT-PCR}

Total RNA was isolated using the SV Total RNA Isolation System Kit (Promega, Milano, Italy) from: a) AFMSCs cells after 20 days culture in standard medium (protocol $1)$; b) differentiated cells after 30 days in osteogenic medium (protocols 1 and 2). RNA from fresh amniotic fluid was also used as a control. One $\mu \mathrm{g}$ of total RNA was reverse transcribed using RETROscript Kit (Ambion, Milano, Italy).

Amplification was performed with specific primers for two classes of genes (table. 1): a) genes expressed in mesenchymal cells (SDF1, CXCR4, Oct-4, SCF, GATA-4, Vim, FGF-5, Pax-6, NCAM, AFP, BMP-2) $(26,28)$; b) genes expressed during osteogenic differentiation (COL1, ONC, OPN, OCN, OPG, BSP and Runx2) [29-31]. Amplifications were carried out using 35 cycles of $95^{\circ} \mathrm{C}, 1 \mathrm{~min}$; variable annealing temperature (see Table 1 ), $1 \mathrm{~min} ; 72^{\circ} \mathrm{C}, 1$ min. RT-PCR products were separated in a $2 \%$ agarose gel and visualized by Ethidium Bromide staining. Images were captured using a Gel Doc 2000 (BioRad, CA, USA).

\section{Cytogenetic investigation}

For cytogenetic analysis, cultures carried out using protocol 2 were treated at day 30 with trypsin and 36-48 hours colcemid. Metaphase chromosomes were stained with GTG-banding and Giemsa. At least 20 metaphases were examined for each sample.

\section{Authors' contributions}

IA carried out cell cultures and osteoblastic differentiation, performed molecular genetics experiments, partecipated to the design of the study and to the drafting of the manuscript. IE carried out cytogenetic investigation. EM partecipated to AF cultures. FM partecipated to AF cells cultures on sample disks. AP prepared osteoblastic cells for SEM analysis. MMB partecipated in osteoblastic cells analysis by SEM. AG carried out osteoblastic cells analysis by SEM. VS partecipated in the design of the study. GC provided human AF samples. ST partecipated to the design of the study and to the drafting of the manuscrupt. GP partecipated in the design of the study and performed 
Table I: Genes analyzed in RT-PCR experiments, primer sequences and annealing temperature.

\begin{tabular}{|c|c|c|c|c|}
\hline Gene & Gene symbol & Primer Sequences & Annealing temperature & Size (bp) \\
\hline Stromal cell-derived factor-I & SDFI & $\begin{array}{l}F-\text { gacccgcgctcgtccgcc } \\
R-\text { cgggtcaatgcacacacttgtcta }\end{array}$ & $57^{\circ}$ & 262 \\
\hline Chemokine (C-X-C motif) receptor 4 & CXCR4 & $\begin{array}{l}F-\text { agctgttggctgaaaaggtgg } \\
R-\text { gcgcttctggtggcccttgga }\end{array}$ & $60^{\circ}$ & 260 \\
\hline Octamer-binding transcription factor 4 & Oct-4 & $\begin{array}{l}F-\text { cgt gaa gct gga gaa gga gaa gct g } \\
R-\text { caa ggg ccg cag ctc aca cat gtt } c\end{array}$ & $60^{\circ}$ & 245 \\
\hline Stem cell factor & SCF & $\begin{array}{l}\mathrm{F}-\mathrm{cca} \text { ttg atg cct tca agg ac } \\
\mathrm{R}-\mathrm{ctt} \text { cca gta taa ggc tcc aa }\end{array}$ & $62^{\circ}$ & 275 \\
\hline GATA binding protein 4 & GATA-4 & $\begin{array}{l}F-\text { ttc ctc ttc cct cct caa at } \\
R-\text { tca gcg tgt aaa ggc atc tg }\end{array}$ & $60^{\circ}$ & 194 \\
\hline Vimentin & Vim & $\begin{array}{l}\mathrm{F}-\text { tca gcg tgt aaa ggc atc tg } \\
\mathrm{R}-\mathrm{cct} \text { tcg tga ata cca cg acct gc }\end{array}$ & $56^{\circ}$ & 321 \\
\hline Fibroblast growth factor 5 & FGF-5 & $\begin{array}{l}F-g c t \text { gtg tct cag ggg att gta gga ata } \\
R-\text { tat cca aag cga aac ttg agt ctg ta }\end{array}$ & $62^{\circ}$ & 434 \\
\hline Paired box 6 & Pax-6 & $\begin{array}{l}\mathrm{F} \text { - aga ttc aga tga ggc tca aa } \\
\mathrm{R} \text { - aat tgg ttg gta gac act gg }\end{array}$ & $60^{\circ}$ & 313 \\
\hline Neural cell adhesion molecule & NCAM & $\begin{array}{l}\mathrm{F}-\text { gag ggg gaa gat gcc gtg atg tg } \\
\mathrm{R}-\text { ata ttc tgc ctg gcc cgg atg gta g }\end{array}$ & $63^{\circ}$ & 269 \\
\hline Bone morphogenetic protein 2 & BMP-2 & $\begin{array}{l}\mathrm{F}-\operatorname{ttg} \operatorname{cgg} \mathrm{ctg} c t c \text { agc atg tt } \\
\mathrm{R}-\operatorname{ttg} \text { cga gaa cag atg caa gat g }\end{array}$ & $62^{\circ}$ & 315 \\
\hline Alpha-fetoprotein & AFP & $\begin{array}{l}F-g t g c t g c a c t t c t t c \text { ata tgc } \\
R-\text { tga cag cct caa gtt gtt cc }\end{array}$ & $60^{\circ}$ & 218 \\
\hline Type I collagen & COLI & $\begin{array}{l}F-\text { ttcctttgcattcatctctca } \\
R-\text { caagtggaccaagcttcctt }\end{array}$ & $58^{\circ}$ & 149 \\
\hline Osteonectin & ONC & $\begin{array}{l}\mathrm{F}-\text { gtctcactggctgtgttgga } \\
\mathrm{R}-\text { aagacttgccatgtgggttc }\end{array}$ & $60^{\circ}$ & 215 \\
\hline Osteopontin & OPN & $\begin{array}{l}F-\text { aggaggaggcagagcaca } \\
R \text { - ctggtatggcacaggtgatg }\end{array}$ & $60^{\circ}$ & 152 \\
\hline Osteocalcin & OCN & $\begin{array}{l}\mathrm{F} \text { - catgagagccctcaca } \\
\mathrm{R} \text { - agagcgacaccctagac }\end{array}$ & $58^{\circ}$ & 315 \\
\hline Osteoprotegerin & OPG & $\begin{array}{l}F-\text { tgctgttcctacaaagttttacg } \\
R-\text { ctttgagtgctttagtgcgtg }\end{array}$ & $60^{\circ}$ & 433 \\
\hline Bone sialoprotein & BSP & $\begin{array}{l}F-\text { ctatggaaggacgccacgcct } \\
R \text { - catagccatcgtagccttgtcc }\end{array}$ & $62^{\circ}$ & 578 \\
\hline Runt-related transcription factor 2 & Runx2 & $\begin{array}{l}\mathrm{F} \text { - gacagaagcttgatgactctaaacc } \\
\mathrm{R}-\text { tctgtaatctgactctgtccttgt }\end{array}$ & $60^{\circ}$ & 169 \\
\hline Glyceraldehyde-3-phosphate dehydrogenase & GAPDH & $\begin{array}{l}F-\text { ccatggagaaggctggg } \\
R-\text { caaagttgtcatggatgacc }\end{array}$ & $60^{\circ}$ & 194 \\
\hline
\end{tabular}


genetic counselling on women undergoing amniocentesis. LS coordinated the study and partecipated to the drafting of the manuscrupt. All authors read and approved the final manuscript.

\section{Acknowledgements}

Authors wish to thank Daniela Di Tizio and Tonia di Giovacchino for their technical assistance.

This study has been supported by a grant of the G. d'Annunzio University to LS and GP.

\section{References}

I. Prusa AR, Hengstschlager M: Amniotic fluid cells and human stem cell research: a new connection. Med Sci Monit 2002, 8(II):RA253-RA257.

2. Prusa AR, Marton E, Rosner M, Bernaschek G, Hengstschlager M: Oct-4-expressing cells in human amniotic fluid: a new source for stem cell research? Hum Reprod 2003, 18: | 489-| 493.

3. In 't Anker PS, Scherjon SA, Kleijburg-van der Keur C, Noort WA Claas FH, Willemze R, Fibbe WE, Kanhai HH: Amniotic fluid as a novel source of mesenchymal stem cells for therapeutic transplantation. Blood 2003, 102:1548-1549.

4. Fauza D: Amniotic fluid and placental stem cells. Best Pract Res Clin Obstet Gynaecol 2004, 18:877-89I.

5. Tsai MS, Lee JL, Chang YJ, Hwang SM: Isolation of human multipotent mesenchymal stem cells from second-trimester amniotic fluid using a novel two-stage culture protocol. Hum Reprod 2004, 19:1450-1456

6. Tsai MS, Hwang SM, Tsai YL, Cheng FC, Lee JL, Chang YJ: Clonal amniotic fluid-derived stem cells express characteristics of both mesenchymal and neural stem cells. Biol Reprod 2006, 74:545-55I.

7. McLaughlin D, Tsirimonaki E, Vallianatos G, Sakellaridis N, Chatzistamatiou T, Stavropoulos-Gioka C, Tsezou A, Messinis I, Mangoura D Stable expression of a neuronal dopaminergic progenitor phenotype in cell lines derived from human amniotic fluid cells. J Neurosci Res 2006, 83: I 190-2006.

8. Cipriani S, Bonini D, Marchina E, Balgkouranidou I, Caimi L, Grassi Zucconi G, Barlati S: Mesenchymal cells from human amniotic fluid survive and migrate after transplantation into adult rat brain. Cell Biol Int 2007, 3 I:845-850

9. De Coppi P, Bartsch G Jr, Siddiqui MM, Xu T, Santos CC, Perin L, Mostoslavsky G, Serre AC, Snyder EY, Yoo J], Furth ME, Soker S, Atala A: Isolation of amniotic stem cell lines with potential for therapy. Nat Biotechnol 2007, 25:100-106.

10. Trounson A: A fluid means of stem cell generation. Nat Biotechnol 2007, 25:62-63.

II. Holden C: Stem cells. Versatile stem cells without the ethical baggage? Science 2007, 315:170.

12. Kaviani A, Perry TE, Dzakovic A, Jennings RW, Ziegler MM, Fauza DO: The amniotic fluid as a source of cells for fetal tissue engineering. J Pediatr Surg 200I, 36:1662-1665.

13. Kaviani A, Guleserian K, Perry TE, Jennings RW, Ziegler MM, Fauza DO: Fetal tissue engineering from amniotic fluid. J Am Coll Surg 2003, 196:592-597.

14. Fuchs JR, Kaviani A, Oh JT, LaVan D, Udagawa T, Jennings RW, Wilson JM, Fauza DO: Diaphragmatic reconstruction with autologous tendon engineered from mesenchymal amniocytes. J Pediatr Surg 2004, 39:834-8.

15. Kunisaki SM, Fuchs JR, Kaviani A, Oh JT, LaVan DA, Vacanti JP, Wilson JM, Fauza DO: Diaphragmatic repair through fetal tissue engineering: a comparison between mesenchymal amniocyteand myoblast-based constructs. J Pediatr Surg 2006, 4:34-9.

16. Kunisaki SM, Freedman DA, Fauza DO: Fetal tracheal reconstruction with cartilaginous grafts engineered from mesenchyma amniocytes. J Pediatr Surg 2006, 41:675-82.

17. Kassem M, Kristiansen M, Abdallah BM: Mesenchymal stem cells: cell biology and potential use in therapy. Basic Clin Pharmacol Toxicol 2004, 95:209-2I4.
18. Mao J], Giannobile WV, Helms JA, Hollister SJ, Krebsbach PH, Longaker MT, Shi S: Craniofacial tissue engineering by stem cells. J Dent Res 2006, 85:966-979.

19. Chiapasco M, Gatti C, Gatti F: Immediate loading of dental implants placed in severely resorbed edentulous mandibles reconstructed with autogenous calvarial grafts. Clin Oral Implants Res 2007, 18(I): 13-20.

20. Sun W, Lal P: Recent development on computer aided tissue engineering - a review. Computer Methods and Programs in Biomedicine 2002, 67:85-103.

21. Branemark PI, Svensson B, van Steenberghe D: Ten-year survival rates of fixed prostheses on four or six implants ad modum Branemark in full edentulism. Clin Oral Implants Res 1995, 6:227-23I.

22. Lekholm U, Zarb GA: Tissue integrated prostheses: osseointegration in clinical dentistry. Chicago: Branemark, Zarb \& Albrektsson Eds; 1985.

23. Ericsson I, Johansson CB, Bystedt H, Norton MR: A histomorphometric evaluation of bone-to-implant contact on machinepreparated and roughed titanium dental implants. A pilot study in the dog. Clin Oral Impl Res 1994, 5:202-206.

24. Wennerberg A, Albrektsson T, Andersson B: Bone tissue response to commercially pure titanium implants blasted with fine and coarse particles of alluminium oxide. Int J Oral Maxillofac Impl 1996, I I (I):38-45.

25. Piattelli A, Scarano A, Piattelli M, Calabrese L: Direct bone formation on sandblasted titanium implant: an experimental study. Biomaterials 1996, 17:1015-1018.

26. Kim J, Lee Y, Kim H, Hwang KJ, Kwon H, Kim SK, Cho DJ, Kang SG, You J: Human amniotic fluid-derived stem cells have caracteristics of multipotent stem cells. Cell Prolif 2007, 40:75-90.

27. Gregory CA, Gunn WG, Peister A, Prockop DJ: An Alizarin redbased assay of mineralization by adherent cells in culture: comparison with cetylpyridinium chloride extraction. Anal Biochem 2004, 329:77-84.

28. Kortesidis A, Zannettino A, Isenmann S, Shi S, Lapidot T, Gronthos S: Stromal-derived factor-I promotes the growth, survival, and development of human bone marrow stromal stem cells. Blood 2005, 105:3793-380I.

29. Gronthos S, Mankani M, Brahim J, Robey PG, Shi S: (Postnatal human dental pulp stem cells (DPSCs) in vitro and in vivo. Proc Natl Acad Sci USA 2000, 97: I3625-13630.

30. Celetti A, Testa D, Staibano S, Merolla F, Guarino V, Castellone MD, lovine R, Mansueto G, Somma P, De Rosa G, Galli V, Melillo RM, Santoro M: Overexpression of the cytokine osteopontin identifies aggressive laryngeal squamous cell carcinomas and enhances carcinoma cell proliferation and invasiveness. Clin Cancer Res 2005, I I:8019-8027.

31. Huojia M, Muraoka N, Yoshizaki K, Fukumoto S, Nakashima M, Akamine A, Nonaka K, Ohishi M: TGF-beta 3 induces ectopic mineralization in fetal mouse dental pulp during tooth germ development. Dev Growth Differ 2005, 47:141-152.

Publish with Bio Med Central and every scientist can read your work free of charge

"BioMed Central will be the most significant development for disseminating the results of biomedical research in our lifetime. "

Sir Paul Nurse, Cancer Research UK

Your research papers will be:

- available free of charge to the entire biomedical community

- peer reviewed and published immediately upon acceptance

- cited in PubMed and archived on PubMed Central

- yours - you keep the copyright 